\title{
Knowledge, Perceptions and Effects of Ebola Virus Disease Outbreak on the Pig Value Chain in the Agro- pastoralist District of Luwero, Central Uganda
}

\section{Samuel Majalija ( $\nabla$ saraali67@covab.mak.ac.ug )}

College of Veterinary Medicine, Animal resources and Biosecurity of Makerere University https://orcid.org/0000-0001-6445-9070

\section{Doreen Birungi}

College of Veterinary Medicine, Animal Resources and Biosecurity, Makerere University

\section{Gabriel Tumwine}

College of Veterinary Medicine, Animal Resources and Biosecurity, Makerere University Vishwavidyalaya

Charles Drago Kato

College of Veterinary Medicine, Animal Resources and Biosecurity

\section{Tonny Ssekamatte}

School of Public Health, Makerere University

\section{Michael Ocaido}

College of Veterinary Medicine, Animal resources and Biosecurity

\section{Research article}

Keywords: Ebola, small holder farms, Food security, traditional healers, pig sales

Posted Date: January 11th, 2021

DOI: https://doi.org/10.21203/rs.3.rs-76238/v1

License: @ (i) This work is licensed under a Creative Commons Attribution 4.0 International License. Read Full License

Version of Record: A version of this preprint was published at BMC Infectious Diseases on July 9th, 2021. See the published version at https://doi.org/10.1186/s12879-021-06337-8. 


\section{Abstract}

Background: Ebola outbreaks have continued to affect the health, wellbeing and livelihoods of communities. In particular, Ebola response interventions affect food value chains, food and income security of pig farming communities. There is paucity of information on the effect of Ebola outbreak on the pig value chain as well there is a gap on the knowledge and perceptions of those engaged in the pig value chain on Ebola. Therefore, this study aimed at assessing the knowledge, perceptions on the occurrence of Ebola and its effects on the pig value chain in the agro-pastoral district of Luweero, Central Uganda.

Methods: A cross sectional study was conducted in two parishes of Ssambwe and Ngalonkulu, Luwero district. A total of 229 respondents were included in the study. Structured questionnaires, key informant interviews and focus group discussions were conducted to collect data. Quantitative data was analysed using SPSS version 22 while qualitative data was analysed using thematic content analysis.

Results: Of the 229 respondents, $95.6 \%$ could recall the occurrence of the last Ebola outbreak in their locality. The proportion of respondents that associated touching pigs or eating pork with acquisition of Ebola virus was $24.5 \%$. Ebola was perceived as a spiritual manifestation of witchcraft activities. Traditional healers were among the first line of health care providers to Ebola patients in the outbreak. There was no significant association between the perceived human practices such as bush meat consumption, contact with wild animals and acquiring of Ebola virus. The number of pigs sold during the outbreak was significantly reduced $(p=0.001)$ and this normalized 2 months after the area was declared Ebola free. There was a significant reduction $(p=0.03)$ in consumption of pork, as well as the unit cost per kilogram of pork during the Ebola outbreak due to fear of acquiring the disease from pork.

Conclusion: The study showed that the pig value chain was negatively affected by Ebola outbreak. Therefore, there is need to sensitize the stakeholders on Ebola in order to minimize the negative economic impacts associated with EVD outbreaks.

\section{Background}

Ebola Virus Disease (EVD) remains a serious public health problem of global concern. Since the first occurrence, 44 years ago in the Democratic Republic of Congo (formerly Zaire), over 38 Ebola outbreaks have been reported [1]. Ebolavirus is a filovirus in the family Filoviridae consisting of four species that cause human illness; Zaire ebolavirus, Bundibugyo ebolavirus, Sudan ebolavirus and Taï Forest ebolavirus (also known as Cote d'Ivoire ebolavirus) [2]. While Reston ebolavirus is only known to cause infection in domestic pigs [3, 4] and possibly pigs could amplify this virus and potentially transmit it to humans in future. Ebola seropositive samples have been detected from bats, making them the most probable reservoir species of virus, although no virus has been isolated [5]. Similarly, viral antibodies have been identified in gorillas, chimpanzees, and duikers as other possible sources of infection $[5,6]$.

Ebola outbreaks have occurred in sub-Sahara Africa, largely in the West African countries of Guinea, Liberia, Senegal, Sierra Leone and Nigeria, as well as Uganda, Sudan and Democratic Republic of Congo in east and central Africa [1]. Between 2014 and 2016, the largest EVD outbreak to date, occurred in West African countries causing death to over 11,000 people and severe economic damage [7]. Uganda and her neighbours (Democratic Republic of Congo and Sudan) continue to experience frequent Ebola outbreaks [6]. In the past two decades, 
Uganda alone has had six outbreaks in different districts: Gulu in 2000, Bundibugyo (2007), Kibaale (2012), Luwero in 2011 and 2012 and Kasese in 2019 [8]. The first and biggest Ebola outbreak registered 425 cases with a case fatality rate (CFR) of 53\%, while the central district of Luwero experienced two outbreaks in 2011 and 2012 , respectively [9]. Considerably, Uganda remains vulnerable to Ebola outbreaks particularly in the wake of frequent outbreaks and possible spill over from her neighbours [6].

Besides human health, Ebola outbreaks affect agricultural production in the country. Ebola epidemics are associated with movement restrictions of people and their animals in and out of the affected communities, and disruption of the food value chain from the farm to consumers [10-12]. Considerably, families face belowaverage production levels, coupled with market disruptions lead to low purchasing power and reduced incomes [13]. In consequence, food insecurity, fear, social, political and economic turmoil escalate in the affected and atrisk communities.

Agriculture and specially, the pig industry in Uganda, is crucial role in supporting livelihoods by providing nutritional and income security for 1.1 million smallholder farmers [14]. The country's rapid growth of the pig population, at present standing at 1.1 million, is attributed to the high financial returns, low cost of production and increased demand for pork [15]. On the whole, urban and peri-urban consumers account for $70 \%$ of consumed pork, accessed through the informal local butcheries and pork eateries referred to as 'pork joints' [16].

Evidently, the zoonotic epidemics such as Ebola cause wide economic impacts beyond the health sector. At present, information on the effect of Ebola outbreaks on the pig value chain in Uganda in general and Luwero district in particular is scanty. Likewise, little is known about the knowledge and beliefs of the rural communities along the pig value chain in Luwero with regard to Ebola outbreaks. Thus, this study assessed the knowledge, perceptions and effects of Ebola outbreaks along the pig value chain in Luwero District. In essence, this study results will guide future plans to mitigate food insecurity and other consequences associated with Ebola outbreaks in communities that rely on pig production.

\section{Materials And Methods}

\section{Study design}

This cross-sectional study was conducted in Luwero district, located at $0.8271^{\circ} \mathrm{N}, 32.6277^{\circ} \mathrm{E}$ in the Central Region of Uganda (Figure.1) from May to July, 2014. Largely, the district's economic activity is based on rain-fed agriculture and agro-pastoral livestock husbandry practices for $85 \%$ of the population. Pig husbandry practiced by small holder farmers is mainly the traditional free range combined with tethering of the animals [17]. The district consists of thirteen sub-counties, of which Ebola occurred in Kakute village, Ssambwe parish, Nyimbwa subcounty in May, 2011 and Nakisamata village in Ngalonkulu parish, Zirobwe sub-county in December, 2012, [18]. One case was reported in Ngalonkalu parish involving a 12-year-old girl who later died of the disease [19]. In Ssambwe parish, the index case was a 32-year-old motorbike taxi rider Islamic man [20]. He died in hospital and was buried without following safe burial practice because the cause of death has not been established. In total six Ebola cases were confirmed, including four deaths [21].

\section{Eligibility criteria}


The study population involved actors along the pig value chain who fulfilled the eligibility criteria. These were small holder farmers with at least 2 pigs. Pig traders involved in sale of pigs, owners of pork-eateries and consumers of pork. Also, households that had registered Ebola related illness or death were included in the study. While small holder farmers with 2 pigs or less, had other livestock other than pigs, and respondents that did not consent or did not report Ebola related illness/death were not considered for the study.

\section{Sampling strategy of study respondents}

This study used both qualitative and quantitative methods. A structured questionnaire was used to collect quantitative data from individual respondents along the pig value chain. From each parish of Ssambwe and Ngalonkalu, an index villages where Ebola outbreak occurred, were purposefully selected. The criteria for selecting the remaining three villages in each parish was basing on a shared common border(s) with the index villages for Ebola and having a major road connecting the index to other villages. The adult population (>18 years) in the two parishes was estimated at 6000 persons with $60 \%$ engaged in any form of livestock farming, and $40 \%$ (1440 persons) in the pig value chain [15]. A total of 227 respondents was targeted representing about $16 \%$ of population actively engaged in the pig value chain. The key aspects considered included respondents' sociodemographics, level of knowledge on Ebola, perception, and effects on pig production, trade and consumption of pork.

The qualitative study utilized focus group discussions (FGDs) and key informant interviews (KIIs) to get an indepth understanding of the provided data. A total of eight key informants that were conversant with the chronology of Ebola outbreaks in Luwero district were selected for in-depth interviews. These included the community development officer, animal husbandry officers, local council leaders, the district health officer, and village health team members.

A total of four FGDs, two in each parish, composed of 8-10 respondents were conducted for the pig farmers, pig traders (butchers and pork eateries) and pork consumers. An open-ended interview guide was used by a moderator in the local language. FGDs were used to explore the knowledge, possible risk factors and effects of Ebola virus disease along the pig value chain. Deliberately, respondents from the two index villages, and women were among the participants. A digital recorder was used to capture the discussions which were later transcribed into English. An informed verbal consent was obtained prior to this. Each session lasted ninety minutes and ended when subsequent discussions produced no new information [22]. Each FGD was comprised of different categories of respondents which was anticipated to obtain contrasting perspectives that could enrich the discussion. Deliberate efforts were made to include females in the FGDs in the male-dominated community. Mixed gender groups tend to improve the quality of discussions and its outcomes [23].

\section{Data management and statistical analysis}

Qualitative data from recorded audios was transcribed verbatim and cross-checked to ensure completeness of data by experienced research associates. A thematic content analysis approach was used for analysis of key emergent themes [24].

Quantitative data was entered in Microsoft Excel and exported to SPSS version 22 for statistical analysis. Descriptive analysis was used to summarize demographic characteristics of respondents.

Respondents' knowledge about Ebola Virus Disease was categorised as agree, disagree or I don't know. 
Univariate analysis of categorical data was used in identification of potential risk factors to Ebola. The Chi-square test and Fischer's exact tests were used for cross tabulations. Co-efficient regression was used to investigate associations between the variables and the outcomes. Variables were considered significant at $p$-value $<0.05$. Graph Pad Prism version 6 software was used to carry out repeated measures of analysis of variance (ANOVA) to test the effect on the pig sales at various levels in the pig value chain. Variables were considered significant at $p$ value $<0.05$.

\section{Results}

\section{Respondents' socio demographic characteristics}

Table 1 summarizes the socio-demographic characteristics of 229 respondents that were involved in the study. Slightly more respondents 121 (52.8\%) were from Ssambwe parish, almost half $115(50.2 \%)$ were males, most $141(61.6 \%)$ attained at least primary level education and majority $184(80.4 \%)$ were farmers. Regarding involvement in pig value chain, most $142(62 \%)$ of the respondents were pig farmers, and few $20(8.7 \%)$ were pig traders. 
Table 1

Summary of the respondents' demographic characteristics

\begin{tabular}{|c|c|c|c|c|}
\hline \multirow{3}{*}{ Variable } & \multirow{3}{*}{ Attribute } & \multicolumn{2}{|c|}{ Parish $(\mathrm{N}=229)$} & \multirow[t]{3}{*}{ Total } \\
\hline & & Ngalonkulu & Ssambwe & \\
\hline & & $n=108$ & $n=121$ & \\
\hline \multirow[t]{2}{*}{ Sex } & Male & $52(48.1 \%)$ & $63(52.1 \%)$ & $115(50.2 \%)$ \\
\hline & Female & $56(51.9 \%)$ & $58(47.9 \%)$ & $114(49.8 \%)$ \\
\hline \multirow[t]{3}{*}{ Household Head } & Husband & $53(49.1 \%)$ & $52(43.0 \%)$ & $104(45.4 \%)$ \\
\hline & Wife & $41(38.0 \%)$ & $46(38.0 \%)$ & $87(38.4 \%)$ \\
\hline & Child & $14(13.0 \%)$ & $23(19.0 \%)$ & $37(16.2 \%)$ \\
\hline \multirow[t]{4}{*}{ Level of Education } & None & $15(13.9 \%)$ & $11(9.1 \%)$ & $26(11.4 \%)$ \\
\hline & Primary & $71(65.7 \%)$ & $70(57.9 \%)$ & $141(61.6 \%)$ \\
\hline & Secondary & $22(20.4 \%)$ & $37(30.5 \%)$ & $59(25.7 \%)$ \\
\hline & Tertiary & $0(0 \%)$ & $3(2.5 \%)$ & $3(1.3 \%)$ \\
\hline \multirow[t]{5}{*}{ Occupation } & Farmer & $97(89.8 \%)$ & $87(71.9 \%)$ & $184(80.4 \%)$ \\
\hline & Employed & $2(1.9 \%)$ & $15(12.4 \%)$ & 17(7.4\%) \\
\hline & Non-employed & $2(1.9 \%)$ & $6(5.0 \%)$ & $8(3.5 \%)$ \\
\hline & Business & $7(6.5 \%)$ & $13(10.7 \%)$ & $20(8.7 \%)$ \\
\hline & (trader) & & & \\
\hline \multirow[t]{3}{*}{ Role in the pig value chain } & Pig farmers & $71(65.7 \%)$ & $71(58.7 \%)$ & $142(62 \%)$ \\
\hline & Pig traders & $7(6.5 \%)$ & $13(10.7 \%)$ & $20(8.7 \%)$ \\
\hline & Pork consumers & $30(27.8 \%)$ & $37(30.6 \%)$ & $67(29.3 \%)$ \\
\hline
\end{tabular}

\section{Respondents' knowledge about Ebola Virus Disease}

Respondents were assessed on their ability to recall the occurrence of an Ebola outbreak in the parish or neighbouring village; knowledge of transmission; clinical manifestation and treatment of the disease. Out of the 229 respondents, 219 (95.6\%) could recall the occurrence of an Ebola outbreak in their locality (Table 2).

On transmission, a significant number $(p<0.001)$ of correctly associated Ebola transmission with handling Ebola infected persons 194 (84.7\%), migration of people from endemic areas 191 (83.4\%), eating monkey meat 148 (64.9\%), eating bats 127 (55.5\%) and conducting public meetings where there is an Ebola infected person 198 (64.9\%). It was also noted that $56(24.5 \%)$ of respondents associated eating pork or touching pigs to Ebola transmission (Table 2). 
Table 2

Respondents knowledge of Ebola virus disease transmission

\begin{tabular}{|c|c|c|c|c|}
\hline \multirow[b]{2}{*}{ Knowledge assessment } & \multicolumn{2}{|c|}{ Response (\%) } & \multirow[b]{2}{*}{ I don't know } & \multirow[b]{2}{*}{$\mathrm{p}$-value } \\
\hline & Agree & Disagree & & \\
\hline \multicolumn{5}{|l|}{ i) Ability to recall } \\
\hline Ability to recall occurrence of Ebola outbreak & $219(95.6 \%)$ & $8(3.5 \%)$ & $2(0.9 \%)$ & $<0.001$ \\
\hline \multicolumn{5}{|l|}{ ii) Transmission mode } \\
\hline Handling Ebola Infected persons & $194(84.7 \%)$ & $9(3.9 \%)$ & $25(11.4 \%)$ & $<0.001$ \\
\hline Eating Bush meat & $115(50.2 \%)$ & $45(19 \%)$ & $69(30.1 \%)$ & $<0.001$ \\
\hline Eating monkey meat & $148(64.9 \%)$ & $15(6.6 \%)$ & $65(28.5 \%)$ & $<0.001$ \\
\hline Migration of people from Ebola endemic areas & $191(83.4 \%)$ & $6(2.6 \%)$ & $32(14 \%)$ & $<0.001$ \\
\hline Public meetings with Ebola infected persons & $198(86.5 \%)$ & $6(2.5 \%)$ & $25(10.9 \%)$ & $<0.001$ \\
\hline Eating pork/ touching pigs & $56(24.5 \%)$ & $169(73.8 \%)$ & $4(1.7 \%)$ & $<0.001$ \\
\hline \multicolumn{5}{|l|}{ iii) Ebola clinical signs } \\
\hline Fever & $142(62.3 \%)$ & $5(2.2 \%)$ & $81(35.5 \%)$ & $<0.001^{\mathrm{a}}$ \\
\hline Vomiting Blood & $160(71.1 \%)$ & $3(1.3 \%)$ & $62(27.6 \%)$ & $<0.001^{\mathrm{a}}$ \\
\hline Diarrhea & $171(75.3 \%)$ & $3(1.3 \%)$ & $53(23.3 \%)$ & $<0.001^{\mathrm{a}}$ \\
\hline Hemorrhage & $168(74.0 \%)$ & $4(1.8 \%)$ & $55(24.2 \%)$ & $<0.001^{\mathrm{a}}$ \\
\hline Muscle Pain & $84(37.0 \%)$ & $7(3.1 \%)$ & $136(59.9 \%)$ & $<0.001^{\mathrm{b}}$ \\
\hline Headache & $85(37.1 \%)$ & $10(4.5 \%)$ & $177(79.7 \%)$ & $<0.001^{b}$ \\
\hline Skin rash & $21(9.6 \%)$ & $5(2.3 \%)$ & $192(88.1 \%)$ & $<0.001^{\mathrm{b}}$ \\
\hline Sore throat & $35(15.8 \%)$ & $10(4.5 \%)$ & $177(79.7 \%)$ & $<0.001^{b}$ \\
\hline \multicolumn{5}{|l|}{ iv) Seeking treatment for Ebola virus disease } \\
\hline Traditional healer/witchdoctor & $63(30.1 \%)$ & $131(62.7 \%)$ & $15(7.2 \%)$ & $<0.0001$ \\
\hline Clinics/Hospital (Doctor) & $97(49.2 \%)$ & $78(39.6 \%)$ & $22(11.2 \%)$ & $<0.0001$ \\
\hline Pharmacy (drug shops) & $60(30.5 \%)$ & $112(56.9 \%)$ & $25(12.7 \%)$ & $<0.0001$ \\
\hline Local herbs (Home treatment) & $5(2.6 \%)$ & $169(86.7 \%)$ & $21(10.8 \%)$ & $<0.0001$ \\
\hline Village Health team & $3(1.5 \%)$ & 171 (87.7\%) & $21(10.8 \%)$ & $<0.0001$ \\
\hline
\end{tabular}




\section{Respondents' knowledge of clinical signs associated with Ebola}

Regarding clinical manifestation, bleeding from body openings, fever, vomiting blood and diarrhoea were the signs that most respondents highly associated with Ebola. However, other signs such as muscle pain, headache, rash and sore throat were not associated with Ebola (Table 2).

\section{Knowledge on seeking treatment for Ebola virus disease}

A majority of the study respondents preferred seeking Ebola treatment from clinics and hospitals. However, 63(30.1\%) respondents suggested that an Ebola patient could be treated by a traditional healer. This was supported by the FGDs as quoted 'I always consult our traditional healer before taking my patient to hospital. I have learnt that traditional healers have divine powers to guide us, and most times what they tell us is what comes out'.

\section{Respondents' perception of pigs as the source of Ebola virus disease}

As shown in Table 3 the perception about the source or ways through which Ebola virus disease can be transmitted was assessed. Of 229 respondents, 56(24.5\%) associated occurrence of Ebola to eating or touching pigs while $173(75.5 \%)$ did not associate Ebola virus disease to pigs. Significantly more respondents from Ssambwe (37.2\%) than Ngalonkulu (10.2\%) associated pigs with Ebola in Luwero

Table 3

Respondents' perception of Ebola Virus Disease

\begin{tabular}{|c|c|c|c|c|c|}
\hline \multicolumn{6}{|c|}{ Parish } \\
\hline Variable & Response & Ngalonkulu & Ssambwe & Total & $\mathrm{p}$-value \\
\hline \multirow[t]{2}{*}{ Association of pigs with Ebola } & Yes & $11(10.2 \%)$ & $45(37.2 \%)$ & $56(24.5 \%)$ & \\
\hline & No & 97 89.8\%) & 76 (62.8\%) & $173(75.5 \%)$ & $<0.001$ \\
\hline
\end{tabular}


Table 4

Perceived risk factors and practices that may lead to the occurrence of Ebola

\begin{tabular}{|c|c|c|c|c|c|}
\hline \multirow[t]{2}{*}{ Variable } & \multirow[t]{2}{*}{ Attribute } & \multicolumn{4}{|c|}{ Presence of Ebola } \\
\hline & & With case (\%) & With no cases (\%) & $\begin{array}{l}\text { Correlation } \\
\text { coefficient }\end{array}$ & p-value \\
\hline \multirow[t]{2}{*}{ Bush meat consumption } & Yes & $4(1.7)$ & $111(48.5)$ & -0.005 & 0.933 \\
\hline & No & $4(1.7)$ & $110(48.0)$ & & \\
\hline \multirow[t]{2}{*}{ Consumption of Pork } & Yes & $7(3.1)$ & $92(40.2)$ & 0.105 & 0.11 \\
\hline & No & $1(0.44)$ & $129(56.3)$ & & \\
\hline \multirow[t]{2}{*}{ Monkey meat consumption } & Yes & $7(3.1)$ & $142(62.0)$ & 0.059 & 0.37 \\
\hline & No & $1(0.44)$ & $79(34.5)$ & & \\
\hline \multirow[t]{2}{*}{ Eating Bats } & Yes & $5(2.1$ & $124(54.1)$ & 0.083 & 0.21 \\
\hline & No & $3(1.3)$ & $97(42.4)$ & & \\
\hline \multirow[t]{2}{*}{ Bats in houses } & Yes & $4(1.7)$ & $93(40.6)$ & 0.025 & 0.703 \\
\hline & No & $4(1.7)$ & $128(55.9)$ & & \\
\hline \multirow[t]{2}{*}{ contact with wild animals } & Yes & $0(0.0)$ & $4(1.7)$ & -0.022 & 0.74 \\
\hline & No & $8(3.5)$ & $217(94.7)$ & & \\
\hline \multirow[t]{2}{*}{ Working in a pig enterprise } & Yes & $3(1.3)$ & $17(7.4)$ & 0.214 & 0.132 \\
\hline & No & $5(2.1)$ & $204(89.1)$ & & \\
\hline \multirow[t]{2}{*}{ Farming system } & Yes & $0(0.0)$ & $5(2.1)$ & -0.052 & 0.511 \\
\hline & No & $8(3.5)$ & $216(94.3)$ & & \\
\hline
\end{tabular}

With reference to the perceived risk factors and practices of acquiring Ebola virus, there was no correlation to all factors (Table 4). This was also in concurrence with one of the respondents quoted as in the FGD,

we don't believe that one can contract Ebola from eating monkey meat, we have eaten bush meat for years and none of us has contracted Ebola."

\section{Effect of Ebola outbreak on the demand and sales of pigs and consumption of pork}

Out of 142 farmers, 55 (38.7\%) believed that Ebola outbreaks affected demand of pigs (Table 5). Similarly, from a Focus Group Discussion, where a study participant was quoted,

"....... Ebola outbreaks greatly affected demand for pigs and other farm products. Traders from Kampala did not come to buy pigs during that Period, they feared to acquire Ebola disease." 
Out of the 20 traders, 17 (85\%) were in agreement that Ebola reduced pig sales (Table 5). There was a significant reduction $(P<0.001)$ in pork consumption during Ebola outbreaks. Out of the 67 consumers in this study, 15 (22.4\%) did not consume pork during the Ebola outbreak (Table 5).

In concurrence with FGD, one respondent was quoted as,

"...... I feared to consume pork because I thought I would contract Ebola disease; we were told to avoid consuming any meat during that period."

Table 5

Effect of Ebola outbreak on the pig value chain

\begin{tabular}{|lll|}
\hline Variable & Attribute & Frequency (N) (\%) \\
\hline Reduced Demand & Agree & $55(38.7 \%)$ \\
\cline { 2 - 3 }$($ farmers) & Disagree & $75(52.8 \%)$ \\
\cline { 2 - 3 } & I don't know & $12(8.5 \%)$ \\
\hline Reduction in pig sales & Yes & $17(85 \%)$ \\
\cline { 2 - 3 } (Traders) & No & $3(15 \%)$ \\
\hline Consumed Pork during Ebola outbreak & Yes & $52(77.6 \%)$ \\
\cline { 2 - 3 } & No & $15(22.4 \%)$ \\
\cline { 2 - 3 } & &
\end{tabular}

As in Table 6, there was a significant reduction $(P=0.001)$ in the average number of pigs sold during Ebola outbreak period. There was also a significant reduction $(P=0.04)$ in the average number of pigs bought by traders during the Ebola outbreak. Similarly, it is clearly seen that the number of pigs sold/ slaughtered by butcher men at pork eating places reduced significantly $(P=0.03)$. 
Table 6

Pig sales and price indices during Ebola outbreak period in Luwero district

\begin{tabular}{|c|c|c|c|c|}
\hline \multirow[b]{2}{*}{ Persons involved in pig sales } & \multicolumn{4}{|c|}{ Mean SD (Pigs sold per period) } \\
\hline & Before & During & After & P-value \\
\hline Farmer $\mathrm{N}=142$ & $4 \pm 3$ & $3 \pm 1$ & $3 \pm 2$ & $0.001^{\star}$ \\
\hline Trader $\mathrm{N}=20$ & $4 \pm 3$ & $4 \pm 2$ & $5 \pm 3$ & $0.04^{*}$ \\
\hline Pork butchers $\mathrm{N}=9$ & $7 \pm 3$ & $5 \pm 3$ & $6 \pm 3$ & $0.03 *$ \\
\hline Price indices & Estimated average kg SD) & Price per Kg (USD & USD & \\
\hline Price & $426+255$ & $353+237$ & $326+250$ & \\
\hline Price/kg (US\$) & 2.5 & 1.6 & 1.8 & \\
\hline Total US\$ & 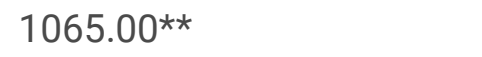 & $564.8^{*}$ & $684.00 * *$ & \\
\hline \multicolumn{5}{|c|}{ *Significantly lower during the Ebola outbreak (Repeated measures ANOVA, P <0.05) } \\
\hline
\end{tabular}

The unit cost of a kilogram of pork reduced during the outbreak. The income generated from pork sales reduced significantly during the outbreak when compared to the period before and after the outbreak (Table 6)

\section{Discussion}

Highly infectious emerging zoonotic diseases such as Ebola are a major cause of morbidity and mortality in Africa [25] as shown by the recent outbreaks in West and Central Africa [7, 26]. The past six Ebola outbreaks in Uganda accentuate the country's vulnerability to further outbreaks, especially due to spill-over from the Democratic Republic of Congo, a neighbouring country prone to frequent Ebola outbreaks [27, 28]. Also, Uganda's location in an area with great biodiversity, together with a fast-rising population density that comingle closely with animals are high risk factors for Ebola and other emerging zoonotic diseases [27, 29].

Our focus on the Ebola outbreak with respect to the pig value chain, was prompted by Uganda's fast growing pig sector, that continues to register increasing pork consumption rates (average of $3.4 \mathrm{~kg} / \mathrm{person}$ per year), the highest in East Africa [30]. Primarily, the national Ebola control programs are designed to protect the human health and remotely consider enterprises that support farmers' livelihoods. However, the neglect of the community's survival and sustenance options, especially the pig value chain could lead to adversative effects on livelihoods. With the recent zoonotic disease prioritization [31] and having the multi-sectoral-multi-agency One health strategic plan in place [32], Uganda has the opportunity to embrace a One Health approach while handling Ebola and other priority zoonotic diseases for the benefit of the community. Effective post-Ebola intervention plans in Uganda and elsewhere, must encompass the primary sources of livelihoods for such agro-pastoral communities in order to mitigate the negative impacts of the disease. For instance, farmers could be provided with breeding pigs, access to credit, and training for the small holder pig enterprises. This is in concurrence with strategies put in place in West Africa in lieu of efforts to stimulate social and economic recovery of vulnerable 
communities affected by Ebola [33]. Ebola control programs cognisant of the inter-sectoral collaboration that would assure sustainable pig production, supply and marketing for the small holder pig farmers in Uganda.

With regards to knowledge, a majority of the respondents were able to recall previous Ebola outbreaks in Luwero that occurred more than two years ago. This was contrary to common health care events, often not recalled accurately within a few months of occurrence [34]. Most likely, the impact of Ebola outbreaks associated with economic turbulence and social stigma in communities appear to last longer. Indeed, people tend to remember disastrous events associated with excessive changes in routine life, even after several years of the incident [35]. One such event was the introduction of 'safe burial' practices for Ebola victims [36]. Whereas this was needed to prevent disease spread, the communities misconstrued the practice as being disgraceful and demeaning to the dead. This is because the bereaved family members were denied a chance to pay their last respect to their dead, (pray, wash, dress, perfume the corpses) and mark the graves of the deceased [36]. In effect, this caused psychosocial trauma among relatives and community members that might have led to long-term memories which lasted for several years, even after the Ebola outbreak.

The fact that respondents were able to identify the major signs and symptoms of Ebola such as fever, vomiting, bleeding and diarrhoea was not unexpected. These were frequently shared on the information education and communication materials that were available in the community health centres and public spaces in Luwero [37]. Communities that are able to identify the main signs of Ebola can ably avoid the infections when such cases occur. However, other important signs which are frequently associated with common ailments such as malaria could not be identified, suggesting that the community could mistakenly handle Ebola patients with minimal or no precautionary measures. This is particularly possible if Ebola presents with nonspecific symptoms that can easily be mistaken for other endemic diseases like malaria, typhoid fever, yellow fever or, even measles or meningococcemia in children [38]. Efforts should be put in place to educate the public to consider patients with such signs as suspected cases, especially when there is an Ebola outbreak in the community.

Besides, the health centres, a significant proportion of patients suspected to have Ebola could be treated by traditional healers or witchdoctors. A number of communities in Uganda and elsewhere in Africa still associate Ebola outbreaks with witchcraft [20]. Traditional healers have evolved with communities in Africa, and continue to offer first line of health care services in Uganda for unknown ailments believed to be associated with witchcraft to appease the spirits $[20,39]$. Nonetheless, escalation of Ebola infections in West Africa and DRC was linked to traditional healers due to inability to adhere to preventative measures [40]. Training traditional healers on the basic preventive measure for Ebola and closely monitoring their operations would minimize spread of the disease in the community.

This study observed mixed perceptions on the transmission of Ebola with a majority linking transmission with eating of bats, monkey and bush meat. This was in conformity with the study conducted by $[5,41,42]$, who noted that consumption of bush meat could contribute to infection. Conversely, the respondents did not consider eating of game meat as a high risk factor, probably because in earlier outbreaks that occurred in Kibaale district [43] and also in Luwero district [20] the victims could not be linked to eating of wild animals such as monkeys before falling ill. Meanwhile, as eating of bats or other wild animals could not be regarded as a high risk for acquiring Ebola, hunting and eating of game meat continues unabated, exposing the vulnerable communities to future Ebola infections. Besides hunting game meat for authentic values, most communities depend on wild game as 
source food and income security. Efforts to provide alternative livelihoods and food security could protect vulnerable communities from Ebola.

Our findings showed that the unit cost of pork was significantly reduced during Ebola outbreak. Also, the average number of kilograms of pork sold as well as the final income significantly reduced during the outbreak. This was in conformity with the assertions that beyond the public health impacts, emerging global infectious cause wider socioeconomic consequences often disregarded in impact assessments [44]. This could be attributed to the human health sector-based Ebola preparedness and prevention practices and the public behaviour of stigmatizing the pigs as the source of Ebola that led to avoidance of eating pork. Evidently, zoonotic infectious disease outbreaks have been associated with substantial economic impacts due to disruption of the livestock markets (44). In consequence, the reduced sales and incomes negatively impacted the household incomes. In accord with prior reports from West Africa, household and community incomes dropped significantly during the Ebola outbreak [45] leading to increased food insecurity and household vulnerability.

A plausible explanation for the reduced sales of pigs/pork was due to the misconception that pigs were the source of Ebola, creating fear of contracting the disease and avoiding eating of pork by the consumers. It was not clear why the community associated pigs with the Ebola. However, the two Ebola outbreaks in Luwero were apparently preceded by African swine fever (ASF) epidemics with wide spread mortalities of pigs in the community. Besides, pigs with ASF show signs of haemorrhages on the skin and in internal organs, labored breathing with frothy nasal discharges mixed with blood, and death of most affected animals within 2-5days [46]. Farmers have frequently observed reddening of the ears, clinical signs consistent with of ASF [47, 48]; but more less the same sign (bleeding) is observed in human cases with Ebola. As a result, the ASF in pigs and Ebola in humans are erroneously believed to be caused by the same agent that originates from pigs. To clear this misconception, a deliberate social-anthropological understanding of the agro-pastoral communities with regard to such diseases should be given priority attention to minimize losses to the pig industry in future.

\section{Conclusion}

There was a significant reduction in pig sales, price per unit cost of a kilogram of pork and pork consumption. On health seeking behavior, traditional healers were preferred as the first line of health care providers to Ebola patients. These may in the long run escalate the outbreak of Ebola since they do not adhere to preventative measures during their ritual practices. There was no correlation of the perceived risk factors to Ebola outbreak and therefore this indicated that probably another unknown factor may have led to Ebola outbreaks in Luwero district. However, the association of Ebola Virus Disease with pigs is detrimental and could affect the entire pig value chain in terms of pig production, pig sales and pork consumption.

\section{Recommendations}

There is need for a One health inter-sectoral collaboration of agricultural and health sectors to while designing preparedness and prevention programs for Ebola and other emerging zoonotic diseases in Uganda. Farmers should be sensitized that pigs are not a source of Ebola. Traditional healers should be trained and their role monitored during future Ebola virus disease outbreaks. Socio-anthropological studies need to be conducted in order to understand the way communities perceive Ebola Virus disease. 


\section{Abbreviations}

ANOVA: Analysis of Variance

ASF: African Swine Fever

CFR: Case Fatality Rate

EVD: Ebola virus disease

FGD: Focus Group Discussion

KII: Key Informant Interview

\section{Declarations}

\section{Ethics approval and consent to participate}

This project was part of the on-going study under the project Capacity Building in Management of Integrated Trans-Boundary Animal Diseases and Zoonoses (CIMTRADZ) for which approval had been granted by the Institutional Review Board. Permission was sought from Luwero District Local Government. We sought verbal informed consent in the local language from respondents (survivors, close relatives of the deceased, and local leaders). The respondents had to be 18 years old and above and willing to be interviewed. They were informed that their participation was voluntary and their refusal would not result in any negative consequences. During data analysis, we used unique identifiers to ensure confidentiality.

\section{Consent for publication}

All others have given their consent to publish the manuscript

\section{Competing interests}

The authors declare that they have no competing interest.

\section{Funding/ Disclaimer}

This study was funded by the Capacity Building in Integrated Management of Trans boundary Animal Diseases and Zoonoses (CIMTRADZ) - HED project. The funders had no role in study design, data collection and analysis, decision to publish, or preparation of the manuscript. Data and any relevant material required will be available.

\section{Author Contributions}

All authors contributed substantially to the write-up and review of the manuscript. DB wrote the drafts of the manuscript and revised the paper for substantial intellectual content. TS and DB were involved in field data 
collection and writing the manuscript. GT and CDK participated in the conceptual design and analysis of data. MO and SM supervised the process of data collection, write up and reviewed the paper for substantial intellectual content. All the authors read and approved the final version of the manuscript.

\section{Acknowledgements}

We appreciate Capacity Building in Integrated Management of Trans boundary Animal Diseases and Zoonoses (CIMTRADZ) - HED project for funding the study. We thank Luwero District Health and Veterinary Offices, and communities from Nyimbwa and Zirobwe sub-counties in Luwero for cooperating during the study. Gratitude also goes to the study participants who dedicated their time during the time of data collection.

\section{Data Availability statement}

Primary data was used to support the findings in this study. The dataset used in this investigation are available from corresponding author upon request.

\section{References}

1. Sanchez A, Ksiazek TG, Rollin PE, Peters CJ, Nichol ST, Khan AS, et al. Reemergence of Ebola virus in Africa. 1995;1(3):96.

2. Park DJ, Dudas G, Wohl S, Goba A, Whitmer SL, Andersen KG, et al. Ebola virus epidemiology, transmission, and evolution during seven months in Sierra Leone. Cell. 161(7):1516-26.

3. Marsh GA, Haining J, Robinson R, Foord A, Yamada M, Barr JA, et al. Ebola Reston virus infection of pigs: clinical significance and transmission potential. 2011;204(suppl_3):S804-S9.

4. Weingartl, H., Embury-Hyatt, C., Nfon, C. Leung A, Smith G, Kobinger GJSr. 2012. Transmission of Ebola virus from pigs to non-human primates. Sci Rep2, 811. https://doi.org/10.1038/srep00811

5. Leroy EM, Epelboin A, Mondonge V, Pourrut X, Gonzalez J-P, Muyembe-Tamfum J-J, et al. Human Ebola outbreak resulting from direct exposure to fruit bats in Luebo, Democratic Republic of Congo, 2007. Vector Borne Zoonotic Dis. 2009;9(6):723-728. doi:10.1089/vbz.2008.016.

6. WHO. Ebola virus disease key facts 2019. p. https://www.who.int/news-room/fact-sheets/detail/ebola-virusdisease.

7. Dixon MG, SchaferlJ. 2014. Ebola viral disease outbreak - West Africa, 2014. MMWR Morb Mortal Wkly Rep. 63(25):548-551.

8. Okware S, Omaswa F, Zaramba S, Opio A, Lutwama J, Kamugisha J, et al. An outbreak of Ebola in Uganda. Trop Med Int Health, 2002; 7(12): 1068-1075.

9. Mbonye A, Wamala J, Winyi-Kaboyo, Tugumizemo V, Aceng J, Makumbi I. Repeated outbreaks of viral hemorrhagic fevers in Uganda. Afr Health Sci. 2012;12(4):579-583. doi:10.4314/ahs.v12i4.31

10. Kodish S, Bio F, Oemcke R, Conteh J, Beauliere J-M, Pyne-Bailey S, et al. 2019. A Qualitative Study Exploring Perceived Impacts of Ebola on Nutrition in Sierra Leone-a Food Value-chain Framework for Improving Future Response Strategies (OR21-07-19). Current Developments in Nutrition. 3(Supplement_1):nzz034. OR21-07-19. 
11. Kodish SR, Rohner F, Beauliere J-M, Daffe M, Ayoya MA, Wirth JP, et al. Correction: Implications of the Ebola virus disease outbreak in Guinea: Qualitative findings to inform future health and nutrition-related responses. PLOS ONE 13(10): e0204675.

12. Elston J, Cartwright C, Ndumbi P, Wright J. 2017. The health impact of the 2014-15. Ebola outbreak. Public Health, 143, 60-70.

13. Food and Agriculture Organization, 2016. Impact of the Ebola virus disease outbreak on market chains and trade of agricultural products in West Africa. Food and Agriculture Organization of the United Nations Dakar. http://www.fao.org/emergencies/resources/documents/resources-detail/en/c/417072/. Accessed on 25 July 2020

14. Uganda Bureau of Statistics 2016. The National Population and Housing Census 2014-Main Report. Available from: http://www.ubos.org/onlinefiles/uploads/ubos/NPHC/2014\%20National\%20Census\%20Main\%20Report.pdf.

15. Atherstone C, Roesel K, Grace D. 2014. Ebola risk in the pig value chain in Uganda. Report number: Research Report 34. International Livestock Research Institute. https://www.ilri.org/publications/ebola-risk-pig-valuechain-uganda

16. Roesel K, Ejobi F, Dione M, Pezo D, Ouma E, Kungu J, Clausen P-H, Grace D. 2019. Knowledge, attitudes and practices of pork consumers in Uganda. Global Food Security. 20:26-36. https://doi.org/10.1016/j.gfs.2018.12.001

17. Muhanguzi D, Lutwama V, Mwiine FN. 2012. Factors that influence pig production in Central Uganda-Case study of Nangabo Sub-County, Wakiso district. Vet World 2012;5(6):346-51.

18. Shoemaker T, MacNeil A, Balinandi S, Campbell S, Wamala JF, McMullan LK, et al. Reemerging Sudan ebola virus disease in Uganda, 2011. 2012. Emerg Infect Dis.18(9):1480.

19. World Health Organization 2011. Ebola in Uganda. https://www.who.int/csr/don/2011_05_18/en/

20. De Vries DH, Rwemisisi JT, Musinguzi LK, Benoni TE, Muhangi D, de Groot M, et al. 2016. The first mile: community experience of outbreak control during an Ebola outbreak in Luwero District, Uganda. BMC public health. 16(1):161.

21. Thormar SB. 2013. Evaluation of Ebola response - Uganda. Report. Ugandan Red Cross Society, Kampala. Available: http://adore.ifrc.org/Download.aspx?Fileld=42478\&.pdf

22. Onwuegbuzie AJ, Dickinson WB, Leech NL, Zoran AG. 2009.. A qualitative framework for collecting and analyzing data in focus group research. Int J Qual Meth. 8(3):1-21.

23. Freitas H, Oliveira M, Jenkins M, Popjoy O. 1998. The Focus Group, a qualitative research method. ISRC, Merrick School of Business, University of Baltimore (MD, EUA), WP ISRC No. 010298, pp 22.

24. Kondracki NL, Wellman NS, Amundson DR 2002. Content analysis: Review of methods and their applications in nutrition education. Journal of Nutrition Educationand Behavior. 34(4): 224 - 230.

25. Bruce J, Brysiewicz P. Ebola fever: the African emergency. Int J Trauma Nurs. 2002;8(2):36-41. doi:10.1067/mtn.2002.123083

26. World Health Organization 2018. Ebola Virus Disease-Democratic Republic of the Congo. Disease outbreak news 28 December 2018. https://www.who.int/csr/don/28-december-2018-ebola-drc/en/.

27. Nyakarahuka L, Ayebare S, Mosomtai G, Kankya C, Lutwama J, Mwiine FN, Skjerve E. 2017. Ecological Niche Modeling for Filoviruses: A Risk Map for Ebola and Marburg Virus Disease Outbreaks in Uganda. PLOS 
Currents Outbreaks. Sep 5 . Edition 1. doi:

10.1371/currents.outbreaks.07992a87522e1f229c7cb023270a2af1

28. World Health Organization 2019. Confirmation of case of Ebola virus disease in Uganda.

https://www.afro.who.int/news/confirmation-case-ebola-virus-disease-uganda.

29. Jones KE, Patel NG, Levy MA, Storeygard A, Balk D, Gittleman JL, et al. Global trends in emerging infectious diseases. Nature. 2008;451(7181):990-993. doi:10.1038/nature06536 3.

30. Food and Agriculture Organization of the United Nations, 2018. Pig meat supply quantity (kg/capita/yr) in Uganda [WWW Document]. FAOSTAT. Food Supply - Livest. Fish Prim. Equiv.

URL ঢhttp://www.fao.org/faostat/en/\#data/CL/visualize[

31. Sekamatte M, Krishnasamy V, Bulage L, Kihembo C, Nantima N, Monje F, et al. (2018) Multisectoral prioritization of zoonotic diseases in Uganda, 2017: A One Health perspective. PLoS ONE 13(5): e0196799. https://doi.org/10.1371/journal.pone.0196799

32. Uganda One Health Strategic Plan 2018-2022: http://library.health.go.ug/publications/policydocuments/uganda-one-health-strategic-plan-2018-2022

33. World Bank 2015. Reviving Agriculture in Ebola-hit Guinea, Liberia and Sierra Leone [Internet]. 2015 [cited 22 June 2020]. Available from: https://www.worldbank.org/en/topic/agriculture/brief/reviving-agriculture-inebola-hit-guinea-liberia-and-sierra-leone.

34. Kjellsson G, Clarke P, Gerdtham UG.2014. Forgetting to remember or remembering to forget: a study of the recall period length in health care survey questions. J Health Econ. 2014;35:34-46.

doi:10.1016/j.jhealeco.2014.01.007

35. Becker JS, Paton D, Johnston DM, Ronan KR, McClure J. 2017. The role of prior experience in informing and motivating earthquake preparedness. Int JDisaster Risk Reduction 22:179-193.

36. CDC, 2015. Guidance for Safe Handling of Human Remains of Ebola Patients in U. S. Hospitals and Mortuaries. https://www.cdc.gov/vhf/ebola/clinicians/evd/handling-human-remains.html

37. World Health Organization 2014. Ebola Virus Disease response plan. Available from: www.who.int/ebola/evd-outbreak-response.

38. Beeching NJ, Fenech M, Houlihan CF. Ebola virus disease. BMJ. 2014 Dec 10;349:g7348. doi: 10.1136/bmj.g7348. PMID: 25497512; PMCID: PMC4707720.

39. Hewlett, B. S., \& Amola, R. P. (2003). Cultural contexts of Ebola in northern Uganda. Emerging infectious diseases, 9(10), 1242-1248. https://doi.org/10.3201/eid0910.020493

40. Roca A, Afolabi MO, Saidu Y, Kampmann B. Ebola: a holistic approach is required to achieve effective management and control. J Allergy Clin Immunol. 2015;135(4):856-867. doi:10.1016/j.jaci.2015.02.015

41. Olivero ,J.E., J., Farfán, M.Á., Márquez, A.L., Duarte, J., Nackoney, J., Hall, A., Dupain, J., Seymour, S., Johnson, P.J., Macdonald, D.W., Real, R. and Vargas, J.M. (2015), Correlates of bushmeat in markets and depletion of wildlife. Conservation Biology, 29: 805-815. doi:10.1111/cobi.12441

42. World Health Organization, 2016. Ebola virus disease fact sheet. http://www.who.int/mediacentre/factsheets/fs103/en/.

43. World Health Organization, 2012. End of Ebola outbreak in Uganda. Global Alert and Response (GAR) Disease Outbreak News (DONs). https://www.who.int/csr/don/2012_10_04/en/. 
44. Kristine M. Smith, Catherine C. Machalaba, Richard Seifman, Yasha Feferholtz, William B. Karesh, (2019). Infectious disease and economics: The case for considering multi-sectoral impacts, One Health, 7. https://doi.org/10.1016/j.onehlt.2018.100080.

45. United Nations Development Group(UNDG) - Western and CentralAfrica. 2015. "Socio-Economic Impact of Ebola Virus Disease in West African Countries: A call for national and regional containment, recovery and prevention. https://www.undp.org/.../Reports/ebola-west-africa.pdf.

46. FAO 2000. Manual on meat inspection for developing countries. www.fao.org/3/t0756e/t0756e05.htm

47. Dione, M. M. et al.Risk Factors for African Swine Fever in Smallholder Pig Production Systems in Uganda. Transbound. Emerg. Dis.1-11 (2015). doi:https://doi.org/10.1111/tbed.12452

48. Chenais, E., Boqvist, S. \& Sternberg-Lewerin, S. Knowledge, attitudes and practices related to African swine fever within smallholder pig production in northern Uganda. Transbound EmergDis. 2017; 64 (1):101-115. doi: $10.1111 /$ tbed.12347

\section{Figures}

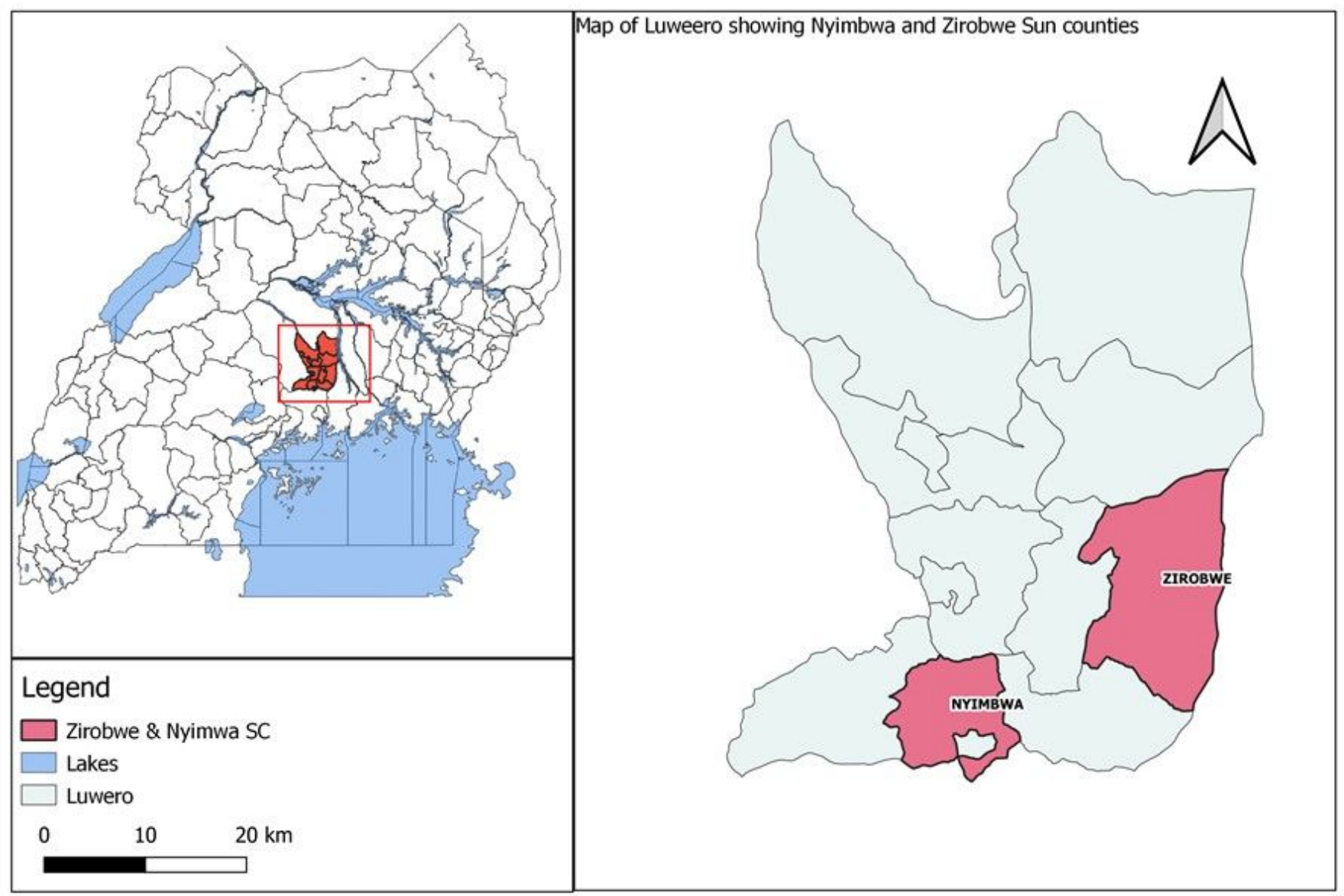

Figure 1 
Map of Uganda showing Zirobwe and Nyimbwa sub-counties in Luwero District. Note: The designations employed and the presentation of the material on this map do not imply the expression of any opinion whatsoever on the part of Research Square concerning the legal status of any country, territory, city or area or of its authorities, or concerning the delimitation of its frontiers or boundaries. This map has been provided by the authors.

\section{Supplementary Files}

This is a list of supplementary files associated with this preprint. Click to download.

- STROBEchecklistv4combinedPlosMedicine.docx 